\title{
Exomologesis as an absolute form of standing in inter-religious dialogue
}

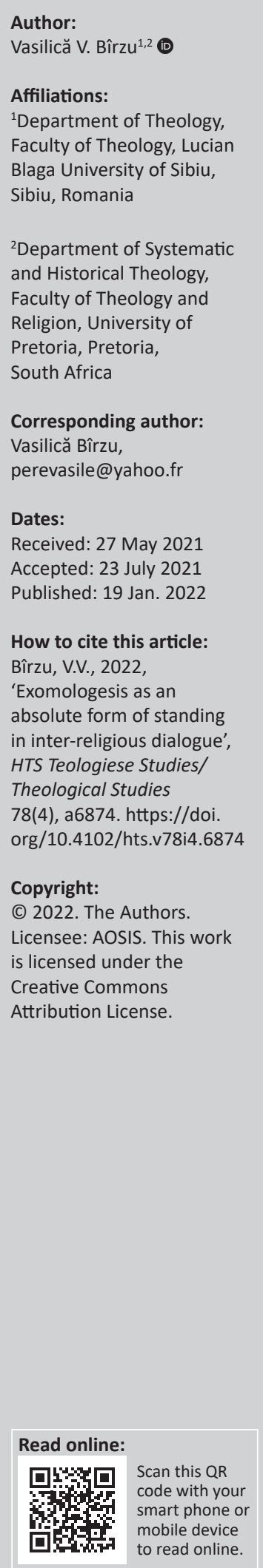

The present study intends to offer another perspective over the inter-religious dialogue emphasising the spiritual state of exomologesis as an essential means of accomplishing a better and real understanding of a participant in dialogue. It makes some short analysis of penitential confession as homologation with the Logos, of the prayer as inner dialogue or confession or exomologesis with the Logos and of the confessions as a literary style, which all engages the deep, spiritual dimensions of communion with the Logos and finally analyses and exemplifies the ecstatic and existential spiritual dimensions of the exomologesis as an absolute form of standing in dialogue.

Contribution: The study offers the necessary spiritual understanding and impulse for a more efficient inter-confessional and inter-religious dialogue, promoting HTS Journal as a herald of this dialogue essential and indispensable for the life of the world.

Keywords: inter-religious dialogue; confession; exomologesis; homologia; healings of memory.

\section{The crisis of the ecumenical dialog and some spiritual solutions for it}

The need to write on this subject arises as a necessity to us because of the blockage, which is generally felt in the ecumenical dialogue. Because this blockage is creating delusion and damages and it is provoking the religious and churchly life of the Christian believers, many are waiting for substantial and real positive results in view of Christian unity. Also, I must recognise that I was pushed to think about the testimonial nature of dialogue, by an observation from Christos Yannaras. He (1997) states that the inter-confessional and inter-religious ecumenical dialogue must 'begin with a confession of sins from the part of each Church', in other words, an exomologesis:

I dream of an ecumenism which will begin with a confession of sins on the part of each Church. If we begin with this confession of our historic sins, perhaps we can manage to give ourselves to each other in the end. We are full of faults, full of weaknesses which distort our human nature. But Saint Paul says that from our weakness can be born a life which will triumph over death. I dream of an ecumenism that begins with the voluntary acceptance of that weakness. Perhaps you will forget most of what I say. But I would ask that you remember this one sentence: the most difficult thing in one's personal life - I do not mean in one's spiritual life, but in one's personal life - is to distinguish between what is real and what is psychological. Our civilization has replaced ontology with psychology. And I do not mean the science of psychology, which has much to tell us. I mean the psychological illusions which we ourselves create, whether through a purely rational approach or through a kind of moral self-satisfaction. We must overcome these idols in order to touch the reality which is truly theological. We must distinguish between what is real and what is psychological so as to be able one day to sing together that by death one can conquer death. (p. 206)

Also, in the analysis of the entire pallete of words created by the term confession, we were encouraged by the interreligious reconciliation programs in which participants are invited to mutually present traumatising experiences that happened in their communities. These programs, such as Memory healing (developed within inter-confessional and interreligious dialogues) are established so that these experiences can be expressed, recognised and forgiven. They send, practically, techniques accomplished through the early Church practice of confession, to the core of individual and communitary self-reconstruction (exomologesis). Taylor (2008) explains this concept in the following quote:

In exomologesis, the self whose truth is made manifest is thus simultaneously destroyed, and a new, purified self is in the process of being born. Accordingly, one model frequently given for exomologesis was medical: to heal a wound one must first show it to a physician or expose one's woundness. Similarly, to rid oneself of the corruptions of the flesh and to renounce worldly life, one must first show the flesh to another or to the public, acknowledging the truth of the self in order to destroy it. (p. 19) 
In this perspective, we wish to emphasise some deep spiritual dimensions of confession or exomologia as the necessary means and method to overcome the 'purely rational approach' or ... 'the moral self-satisfaction', which are blocking the actual ecumenical dialogue. We think that there is a need for an ontological reconstruction of the ecclesial self (hypostasis) through sincere and intense confession. This will help install in our soul that profound and 'crazy love' of Christ and for the Christ's Church in the ecumenical dialogue. We will make some short analysis of confession as a 'homologation' with the Logos, of prayer as a confession (or exomologesis) and of the sacrament of confession as a literary style, which engages in the deep, spiritual dimensions of communion with the Logos. After that, we will analyse and exemplify the ecstatic and existential spiritual dimensions of the exomologesis as the absolute form of standing in a dialogue.

\section{Penitential confession as a homologia with Christ}

It is the Judeo Christian tradition and Christianity, especially, that defines the ineffable and transfiguring depths of the spiritual practice of the Sacrament of confession. Confessing one's sins reveals the intimate aspects of 'exomologesis' as a homologia of someone's soul with the Logos having the explicit intent of spiritual transformation of the penitent and of the people looking at or reading the confession. As professor I. Kornarakis expresses it, 'This path of return from the broken identity to the plenitude' of 'the beauty of the beginning', through 'atimia', is a method absolutely original that can heal the crisis of identity, which the fallen man wishes to experience. It can be met only in the case of ascetics. Until now, neither psychology nor philosophy, nor other activity of the human spirit indicated a similar method. 'The ladder (of Saint John Climacus) is introduced as a promise to bring back the image of God (the man) to its original beauty' (Kornarakis 1990:40).

Exomologesis, as a confession of sins or as therapy of identity and personality crises, is described by I. Kornarakis as a therapeutic matrimonial relationship between one's own self and the body that bears the same yoke of existence in an interdependency and unity that varies according to one's own sensitiveness or 'insensibility' (Kornarakis 1990:37). It is, in fact, an interior dialogue, a monologue that leads to an introspection of all registers of his conscience and selfsensitivity. Nevertheless, it is worthy to mention that this sensitiveness is really defined by one's relation to the Logos; this fact speaks about the healing and transfiguration of bodily senses, which are transformed by sin and shame, into spiritual senses animated by the Holy Spirit. By this transfiguration, one takes the image or the form of the Logos, one 'logosifies' oneself, as Father Iustin Popovici would say, fulfilling his call to divinity by participation in the dialogue with the Logos, who is central to Creation. By this monologue with himself, man searches to follow and imitate the Logos (to homologate) and to reflect his image resembled by the
Logos. If confession (of sins), that is, exomologesis, and the healing of the identity crisis necessitate this inner dialogue, the same dialogue should be used in solving the crises within the Church and in the whole world by inter-confessional, inter-religious and inter-ideologic dialogue. If mankind truly wishes to end wars, it should look to dialogue, and especially inter-religious dialogue, as the solution to solving its multiple crises. $^{1}$

"'Homologation" consists of analytically exposing "insensitivity"', as Kornarakis states, being the method identical to that of confession (exomologesis) found in Tertullian ${ }^{2}$ or in other patristic authors. Saint John Climacus presents the healing of a monastic community by the public confession of a repented thief, newly converted (Saint John Climacus 1980:83-85) and he clearly emphasises the role of enduring dishonouring - atimia, in the means of the transfiguration of the sensitiveness for the healing of the spiritually ill-man through his passion (p. 94). ${ }^{3}$

The conversion of this subtle psychology from the Sacrament of confession to the domain of inter-confessional, interreligious or inter-ideological dialogue would mean that, indeed, denominations, religions or ideologies that split the Church (the world and creation) should confess their historical errors made against one another. These errors were made many times against one another, which were driven by a selfish, terrifying, interested, group-centred logic. These religions and denominations should confess mistakes and errors of logic in their doctrinary, moral and spiritual systems, to verify their compliance with the divine Logos, who truly sustains the Church and the whole creation, and to bring their ideological systems with the Logos to agreement and, in this manner, there would really exist positive progress as a follow-up of these dialogues.

However, we must underline that the practice of confessionexomologesis in the ecumenical dialogue necessitates maximum sincerity from the participants in the dialogue. This is because, in its absence, 'by the dishonest act of avoiding personal responsibility - substituted with the verbosity of self-lying - the other is constrained to interpose into the other's self' (Kornarakis 1990:41), thus reiterating again the Eve's seduction by the serpent through which the latter cunningly transferred its frustrations on mankind.

1.In order to solve crises, I. Kornarakis (1990:37) says, 'solutions to fleeing and solutions to meeting'. The first solutions do not take the identity crisis seriously and in this way they worsen it. The latter convert it 'ab initio' in an inner dialogue, which brings the one who fights 'face to face, body to body, for spiritual perfection and his brings the on
own self...'.

2.In Liber de poenitentia, Chapter X, 1-3, Tertullian (1979) compares the confession of sins with presenting one's wound in front of a physician, highlighting the central role of affection (shame and implicitly (dis) honouring) that the penitent must vanquish or conquer through exomologesis. Tertullian says that some of those who commit sins 'consider shame more important that salvation, like those who, having some wounds ... avoid to show up in front of the doctors and therefore perish because of their shame... They do not leave room to shame, but have more loss because of it'.

3.Saint John Climacus, The Ladder, Word IV, On Obedience, 55, p. 94. 'Listen to God, my son and do not let yourself be cheated by the spirit of vanity, namely to present your sins as if they were another's and not yours! Because it is impossible that someone frees himself from the decaying status of shame, without feeling it. Many times, the devils succeed either in making us avoid confession or to present our sins as if someone else has committed them, or they will make us ascribe the reasons for doing them to other people'. 
That is why, it is indeed dangerous to dialogue with someone who is not sincere, to be open in an exomologetic confession of the soul and in the sacraments of personal faith towards someone who is not sincere in his wish to spiritually transform himself through dialogue according to the reasons of the Logos.

\section{Prayer as confession}

Here, similarly, there must be emphasised another spiritual nuance implied by the term exomologesis, which is very important for the inter-confessional dialogue that aims at prayer in common. The fact is that exomologesis supposes or is identical to a great extent with the state of prayer that enables man to homologate himself continuously with Christ. Confessing himself to Christ, he checks on his spiritual agreement with the divine law and the divine Person he has to identify himself with. Ontologically, man goes from image to resemblance (with Christ). And this aspect of confession exomologesis - has profound implications for the mission and the unity of Church.

Exomologesis may be considered, in fact, a spiritual technique of the mission of Church. Inner homologation of a man's entire life has consequences on the external mission of the Church, any confession of the Truth to others having root and efficiency in the witnessing of the Truth. We see this in the life of the Saviour Christ who used to isolate Himself and pray at night as a necessity and foundation for his every day mission. Any confession (exomologesis) by prayer has an effect on the confession of truth (martyria) as a mission towards others. The foundation of this intrinsic relation grounds in the centrality and in the compulsory involvement of the Logos in the dialogue, because in confession-exomologesis and in prayer, the one who prays is putting oneself in a relation/tension of homologation, placing oneself into agreement, finding similar and harmonising logoi, to tune oneself to the divine reasons of the Father and Christ, the Logos with whom one enters into dialogue by prayer or by one's existential martyria; this homologation is ordering ideas and relations in the external created world according to the agreement with the Logos noetically realised by man, this being the foundation or the essence of external mission. Practically, the man who prays wins by prayer, mentally, noetically, the one he prays for, or mentally, noetically wins a dispute or a dialogue with the one he converts, because Christ-the Logos is the One through whom they come to the same opinion, belief or faith. ${ }^{4}$ In order to sustain this opinion, we are using the term exomologesis, which is found in the biblical literature and in the Philocalia with this nuance of analysis and inner confession by prayer of a penitent, of a believer, practically speaking about an inner transposition of the practice of public repentance in order to re-include the fallen penitent in the Church, through continuous selfanalysis, through repentance (metanoia), the penitent being in prayer with himself and with Christ.

4.I lam the Way, the Truth and the Life. No one comes to the Father except through $\mathrm{Me}^{\prime}(\mathrm{Jn}$ 14:6)
From this perspective, the common prayer of the different representatives of denominations or religions must have at the base the prayer as a confession (exomologesis), as homologation and inner dialogue - the sincere dialogue with the Logos, with the universal reason of creation and with his individual, particular, personal or communitary conscience and self. This dia-logos or prayer in Spirit and Truth should be done by each person - no matter the religion or denomination - leaving himself conducted, in this manner, to the communion with Christ the universal Logos of creation and of the world.

Dialogue as the prayer or the prayer as a dialogue having this inner, homologic dimension reveals in this way as the spiritual practice, indispensably in order to participate in the inter-religious and inter-confessional dialogue, and is equivalent to the homologation or to the re-agreement and matching or resemblance of all who want to be in the personal and ontological communion in the Church creation as an extension of the intratrinitary unity with Christ the Logos. Surely, even those who do not pray personally to Christ-the Logos, but who want to be honest with themselves and with the elementary logic and the natural law in their monologue, prayer and in their inner confession will progress on their way to abiding in Truth with the help of logic, because creation, being fulfilled with the logic and harmony of Christthe Logos, will help them, revealing to them glimpses from His reasons (logoi) hidden in it. Inter-confessional and religious dialogue must be prayer because placing oneself on rigid, external doctrinary positions - only in Truth, without having the Spirit of the Church by prayer - is not fruitful.

\section{Confessions as literary style and its exomologetic spiritual dimensions}

Another way to practise exomologesis or homologation with the Logos is represented by confessions as literary style. This is, in fact, a mono-logos, a banquet and intimate delight with the Logos, a confession of sins as man's meeting with his own self in order to remake and reborn his ego in another way. In such a way, that ego is now formed ideally according to the Logos through man's strong belief in Christ. And even when man preserves himself in his limited logic, he includes Christ more or less, and other ideals and spiritual models are revealed. However, human logic is constituted according to the model or the archetype of the Logos and that is why, entering into monologue or confessing (or the keeping of a literary or spiritual journal) is equivalent to the entrance on the path with the Logos, on the path of homologation. Thus, the man is comparing personal reasoning with the original one of the Logos, with the purpose to accommodate an entrance to a more profound communion or, in fact, in the inner unity between the self and the Logos or to more perfectly identify himself spiritually in self synergy with the Logos.

By excellency, Blessed Augustin's Confessions are the model of spiritual Confessions written with the obvious intention to 
show the transforming power of the self that comes from an inner monologue or from the dialogue of the soul with God. These Confessions, through divine grace, lead to the reenlightening and spiritual strengthening of the reader:

For the confessions of my past sins, which Thou hast forgiven and covered, that Thou mightest bless me in Thee, changing my soul by Faith and Thy Sacrament, when read and heard, stir up the heart, that it sleep not in despair and say 'I cannot', but awake in the love of Thy mercy and the sweetness of Thy grace, whereby whoso is weak, is strong, when by it he became conscious of his own weakness. (Augustin 1933:242)

The purpose of Blessed Augustin's Confessions, and of all confessions in general, is the spiritual formation that is reflected not only in the author's life but also on the entire humankind. This is because they are kenotic acts that uncover and reveal the self in order to make it a revelation for the entire humankind. Also, it is meant to enter into the divine intimacy out of which and in which people and the world and their deeds become known to each other through the warmth of the purified and transfigured affectivity that only divine grace can share:

To whom tell I this? Not to Thee, my God; but before Thee to mine own kind, even to that small portion of mankind as may light upon these writings of mine. And to what purpose? That whosoever reads this, may think out of what depths we are to cry unto Thee. For what is nearer to Thine ears than a confessing heart, and a life of faith! (Augustin 1933:33)

The same transforming and modelling power of the human spirit was manifested in the autobiographic style of confessions even when it was used by a lay author in modern times, who inspired the Enlightenment and the ideas of the French revolution. In his Confessions, Jean-Jaques Rousseau offers us 'the history of his soul', exposed or totally revealed (p. 10) ${ }^{5}$ in order to constitute thus 'the birth document of modern man'. This evokes the same powerful transfiguration of life accomplished by confession as exomologesis:

$[T]$ he memory (invoked in writing) transforming the event in a work of art and, similarly, in the case of Confessions, into an element of proving the fact that a man 'in his entire nature' is corrupt when he separates from it, and returns to goodness when he finds it. (p. 786)

And as a final exemplification, in his small treatise on meeting and dialogue, the Catholic Bishop Pierre Claverie, who was martyred by Muslims whilst he was shepherding his small ward, understands prayer as a confession, as a means of 'adjustment' or matching or approval of ourselves to or with God, precisely because through prayer, the Christian:

[I]s giving himself firstly to be penetrated by the Word of God, entering into the intimate dialogue between Father and Son, Christian prayer being made in the name of the Son, through Him, with Him, in Him. (Claverie 2015:127)

5.'Je voudrais, écrit Rousseau, pouvoir en quelque façon rendre mon âme transparente .

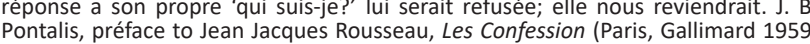
1972:10)

6.Catherine Koenig notice to Jean Jacques Rousseau, Les Confession (Paris, Gallimard 1959 şi 1972:786).

\section{Based on the fact that:}

Jesus came into the world, not to perform miracles, nor to say nice words, but as to give His Spirit for us and make us his children 'adjusted' to the Father. (pp. 128-129)

Christ is giving and offering His Spirit on the Cross, making available to mankind the real means of communication not only verbally, but ontologically through grace by His Spirit, communicating His theanthropic hypostasis as expression and embodiment of prayer and the foundation of 'dialogue of salvation' (p. 137), which God initiates eternally with humanity.

\section{Exomologia as ecstatic and existential dimension of dialogue}

As we can see, through these transformative characteristics, exomologesis represents much more than what homologia meant in classical Greek, which is 'an agreement, assent, compact (in the papyri, of a contract; Deiss., BS, 249), hence $a$ confession' (Abbott-Smith), or in the New Testament a conclusion embraced by common confession (profession, affirmation), or the collective agreement of Christians about what God loves and hates - and the courage to proclaim it.? Exomologesis represents the deepest and most intimate aspect of faith's confession, because it engages the personal and not the general or the doctrinarian belief of someone, but the way a person or community is living its belief. Exomologesis is a personal martyria pushed up to martyrdom, up to the crucification of someone's self and identity. ${ }^{8}$ Jesus Christ gave birth to the Church on the Cross, 'showing His human flesh (nude, without any garment, and whipped and tortured) to the public, acknowledging the truth about his human self in order to destroy it', and be reborn into another, theanthropic, self as a leaven for His pneumatic Body, the Church, a body with a multifaceted divine and human absolute truth. He has accomplished, for humanity, a total and ontological exomologesis, publishing Himself ${ }^{9}$ to the humanity on the Cross as the new reborn (through the divine prototype) humanity in which the selves of the human individuals can merge in the holistic unity of His Body, the Church, because:

$[I] \mathrm{f}$ the act of confession is the performance of the truth of a subject, then exomologesis enacts a multiple truth, a truth of many coinciding but conflicting selves, one geared towards life (i.e., moral redemption), and another destined for death (the symbolic death of the sinner). Both 'truths' coincide within the subject in the moment of exomologesis. (Tembeck 2009:16)

7.cf. Biblehub (https://biblehub.com/greek/3671.htm) about homologia.

8.Foucault cites a fifth-century description of the exomologesis of Fabiola, a Roman noblewoman who remarried before the death of her first husband: During the days that proceeded Easter, Fabiola was to be found among the ranks of the penitents. The bishop, the priests and the people wept with her. Her hair dishevelled, her face pale, her hands dirty, her head covered in ashes, she chastened her naked breast pale, her hands dirty, her head covered in ashes, she chastened her naked breas and the face with which she had seduced her second husband. She revealed to all (Foucault 1993:198-227, esp. 199).
(For wours on her emaciated body

9.Self-publication is the literal meaning of exomologesis, which has also been translated into Latin by Tertullian as 'publicato sui'. See Tertullian (1979:657-668), cited in Foucault (1993:214). 
Through exomologesis, a person imitates the total kenosis and undressing of the Son, of His glory, His death and resurrection on the Cross. Exomologesis is a kind of spiritual unclothing or stripping that produces automatically the ecstatic martyria in the soul of the partner in the dialogue, determining and convincing him to confess the truth and to enter in love with him. Adam, when has seen Eve for the first time, nude, after she was created from his rib, exclaimed and exomologesed or confessed ecstatically that she is 'now bone of my bones, and flesh of my flesh' (Gen 2:23). Similarly, the confession of Christ's divinity by Peter, by the other apostles or by the centurion of the Roman soldiers under the Cross: 'Truly, this Man was the Son of God'! (Mk 15:39, cf and the parallel lines Mt 16:16; Mt 14:33; Mk 3:11; 8:29; Lk 9:20; Jn $1: 49 ; 6: 69 ; 11: 27)$ shows in the best way the ecstatic state in which the confession is made, a state induced as a result of the kenotic wonderful works performed by Christ or the Holy Spirit within the salvation economy. Likewise, the Saviour's word in the Gospel clearly shows that in fact, man does not speak from himself but everything is about a state of inspiration, of theopathy:

But when they arrest you and deliver you up, do not worry beforehand, or premeditate what you will speak. But whatever is given you in that hour, speak that; for it is not you who speak, but the Holy Spirit. (Mk 13:11)

In exomologesis, there is no more a dialogue as much as an evocation or debate of different evidence or martyrias, but a dialogue as invocation, as exclamation, as sighing of truth, of the martyria as an existential truth. Contrary to the general 'logos' debated in dia-logos, confession (or exomologesis) engages the spiritual and affective dimensions of the divine Logos revealed and witnessed in the world by the Father and the Holy Spirit as Their interpersonal Martyria. This Martyria is set as a foundation for the world and for its salvation, different and superior to the general logic and reason from creation, but belonging somehow to the personal logic and reason of the Logos, to the meta-reason and meta-logic ${ }^{10}$ originated in the Holy Spirit, Who being sent in the world, witnesses (confesses the truth) about the Logos (Jn 15:26).

There is this existential, invocative and ecstatic dimension of the martyria inferred in the exomologesis or confession that was understood as the mode of life in the postmartyric period of history in the Church and in the early Christian society when the ascetics and the monks deliberately were intending to continue the sacrifice of the martyrs (as followers of the sacrifice of the Savior). As such, this ecstatic dimension was understood as implicitly existing, also, in the doctrinarian dialogues in ecumenical councils, when their resolutions arrived to be recognised as dogmas by the Church, and it was absent when their resolutions have been rooted in an earthly and sinful logic and wisdom.

10....................................................... and facts as that of Holy Trinity, homoousianity, creation of nothing hypostatical and facts as that of miracles, union, working of miracles, etc. For example, the dogma of the Holy Trinity supposes a special logics, a meta-logics, a logics of the overcoming of the selffounded in the oneness of nature of the Holy Trinity Persons by which hypostases dedicate themselves and overcome one another, one towards the other, the man who opens to this logic admitting the courage to accept as the possible appearance of new features and horizons that had not existed before the opening through dialogue took place, cf. (Botezatu 1997) and Botoşăneanu (2005:66-81).
A good example on the mood and exomologetic and ecstatic spiritual state of a person participating in ecumenical dialogue is described in the preserved document that records the minutes of the meeting between Emperor John VI monk or Ioasaf Cantacuzino and papal legate Paul in June 1367 in Constantinople (Ică 2001:321-331).

The two parties agreed that the 'Unity of the Church' should not be 'with force and tyranny (bia kai tyranidi) but with conviction in the truth and after the order and condition (the instruction) of the Church' as a totally different and far superior or higher to any union or connection between compatriots, relatives, friends, spouses, etc. As the monkking John VI or Ioasaf Cantacuzino expressed it (Ică 2001):

$[M]$ an in his oneness cannot be so united with himself and be one with the spiritual man, that is the Church, because the Church is the body of the Lord, whose head is Christ. [...] The union... of the Church was not pursued by the Latins in a fraternal and friendly manner (kai adelphikos philikos), but in a scholastic, authoritarian and dictatorial mode (didaskalikos kai exousiastikos kai hoinei authentikos), demanding obedience to the pope. (p. 327)

But the striking and eloquent image about the spiritual condition as the confessor of the king-monk negotiator about the union of the Church is expressed trenchant and sarcastic by legate Paul through a metaphor evoking his lack of spiritual sensitivity at the same time by using a comparison from the bucolic, hunter and brigand register - the body of the hunted animal penetrated by a spear and rotated over a campfire, in which soldiers' or hunters' knife cut each strip and the remaining still hang and spin with skewers. The emperor-monk is compared here to 'skewers (soublion) that all (subjects) hang like meat and if you put yourself in motion, also those will be back with you' and so is evoked the unity of the people and of the Church that was in discussion.

Indeed, the Emperor-monk was in a limited spiritual state, with his soul uncovered, such as Romanian proverb says, 'with a roasted heart', really like an impaled rotisserie (soublion) as the Savior's body himself was on the Cross. The lambs sacrificed in the Temple in Old Testament were, also, crucified as an impaled rotisserie to be prepared and eaten by the Jews.

The image is reinforced by being mentioned again twice and the third time by addressing the invitation to the papal legate Paul with the goal of inspiring him to enter together alive into the fire to manifest the truth of the righteous faith practised differently by the two Christian denominations, but the legate refused the invitation:

And if you dare to say that what we did believe and say are not truthful, fairness and justice, let's light a fire and let's get into it'! Paul asking when it would happen, the emperor said: 'I will not rise from this seat until the fire is lit'. Believing that what the emperor said until then were simple words, Paul has given consent; but when persuaded that they were not mere words, but certain things, gave back saying, 'I want to live, not to die'! To which the emperor said: 'I want this also, but being surely 
entrusted that by God's intervention, not only I won't burn for the Orthodox dogma, but that this will be to your benefit, so I dare to go into the fire; but you fear death as if you doubt your faith. (Ică 2001:329)

This dialogue does not only evoke an exalted, impressive medieval magic faith of an emperor-monk sailing fakir confronting the balanced, life-loving and reasonable spirit of the papal legate, but the spiritual condition of existential martyrdom, of sacrifice, of making the final attempt of the Holocaust, of burnt offering to the truth based on an already exomologia certainly fulfilled in the personal life lived by the emperor-monk placed to represent and reveal the incarnate Church itself in the ecumenical dialogue.

To this existential and raised spiritual state, they do not speak or utter vain words but things or sure energies, the legate answers full of platitude urging towards finding solutions on the mundane plan: 'go to the Pope and doing so many good things they will do'; or with a very simplistic logic: 'I do not consider the Christians who are among nonbelievers anything other than those nonbelievers; because they hear Christ's name blasphemed every day, and supports it' (Ică 2001:330).

The test by fire of faith and the confidence of the emperor that he would not burn falling into the fire, found in about the same epoch, also in the life of St. Francis of Assisi, sent us to the Old Testament icon from the prophet Daniel (3:20 ff) about throwing into the fire of the three youths by king Nebuchadnezzar in Babylon, at which appeared someone whose face was like one of the sons of the gods (Dn 3:25) running through the fire and protecting them. Beyond the Trinitarian perspective it was interpreted in the liturgical chanting tradition this Old Testament miracle, a perspective sending to an understanding of the miracle as automanifestation of divine glory in the structure of the Merkava throne composed of three youths in the furnace, the miracle reveals manifestation in extremis - that by the trial of the Holocaust - of the True God when man is asked to lie himself in an idolatrous worship. Therefore, the state of exomologesis is in fact a revelatory means of God's presence in and through men in the world.

Thus, in this perspective, the participation to the dialogue supposes a crucification, a holocausted state of the participants in order to identify themselves with crucified and martyred Christ through the ascetic sacrifice, and Christ to be the One who expresses His heavenly wisdom through the ascetic $\mathrm{He}$ is in dialogue with.

Through the exomologetic spiritual state, the living saints or the living martyrs and confessors, who have died spiritually to the world, are speaking yet in this world, full of heavenly wisdom for the spiritual welfare of the world. And, if the martyr affirms punctually a meta-logic, through the overcoming of death and thus overcomes the logic of this life and of this world, the confessor in the exomologesis spiritual state affirms continuously and mindfully this meta-logic inviting people to live a heavenly life in the Church. It is, also, because of this meta-logic that the martyrium has impressed and convinced people to create religions that are not excelling so much through logic and coherent articulation in the explanation of the man's destiny in the world and towards God but through the madness of sacrifice and killing in the name of a God ${ }^{11}$ (Allah, Baal, etc.). Contrary to this, the exomologesis is impressing through the continuous development of this meta-logic in the historical life of a community confirming the presence of the heavenly life as a sign of the inspirational character of a religion, and in this regard, the Christian confessions and denominations are sharing different degrees of articulation in this meta-logic, revealed and practised through exomologesis.

\section{Conclusions}

Coming back, from this perspective, to the theme of ecumenical dialogue, we may say that its inefficiency in modern times is derived, the way Christos Yannaras would say, from the lack of courage in authentic crucification, totally with and similar to Christ. It derived from the lack of total identification with Christ in His love for His Church and for the mankind. This courage and this power of identification lack both in the case of Christian inter-confessional dialogue and in the case of the inter-religious and inter-ideological ones, because exomologesis, as ascetic practice and spiritual state, is pretty difficult to be understood and practised by the representatives of official and consecrated religions and denominations, who are invited to spiritually raise to 'the crazy love for Christ' and, that is why, practically, one must from the very beginning understand the limits of the ecumenical dialogue as developed, in the actual shape, by official representatives of some theological departments as expressed in formulas of rational faith. On the other side, it is not even recommended to practise exomologesis and the total revealing of one's own or ecclesial communitary self before a community of another denomination, religion or ideology that cannot raise up to understanding and living the sublime dogma of Chalcedon relating to the humandivine hypostasis of Christ. Christ represents the pattern and the standard of the exomologesis model as a practice of authentic homologation of man with God in His Body, the Church. Christ fulfilled on the Cross the homologation of human nature with the divine one, thus founding the Church through a theurgia that only $\mathrm{He}$ as God could have fulfilled. The Holy Fathers of the Church participated truly and beneficially to the development of this Body of Christ - the humanity reconstructed as communion - in the high spiritual state given by confession or exomologesis. The unity of the Church and creation can be realised but through the martyric dimension, through exomologesis in dialogue, because in this way, the Church and all the God's laws and institutions in history have been founded by Him - that means through

11.This is the case of the Islam with its Qur'an as a compilation of texts and religious, mythic and sapiential traditions from Judaism sources and Bible but also of other religions that did not develop a perfect and logic and metaphysically articulated doctrine. 
the bloody sacrifice and Cross. Christ yet warns not to throw the pearls of faith before pigs so that they would not return and tear Him, distort and destroy His pneumatic body, splitting the Church and destroying creation more than before.

Unfortunately, however, modern $\operatorname{man}^{12}$ does not raise up to the level of dialogue as an exomologetic confession of truth, working and uttering theurgia upon facts and doctrines of real faith in order to be able to continue the work of positive creation of humanity begun by Christ the Logos and continued by the Holy Fathers. ${ }^{13}$ These Holy Fathers expressed themselves as confessors and persuasive in crisis situations. In the dialogue as exomologetic confession, targeting the ultimate purpose of communion, only the saints, the wise and those who experienced the death and resurrection of Christ the Logos can participate by dialoguing and highly confessing the truth.

From this perspective, mainly that of the ultimate purpose of spiritual, ideological or sacramental communion, the reserved attitude of those restive in the ecumenical, interconfessional, inter-religious and, generally, inter-ideological dialogue is somehow justified, all denominations, religions and ideologies lack such endurers. This is why, precaution and restraint are necessary or, sometimes, even the avoidance of dialogue, which would target the ultimate purpose of the meta-truth of faith and communion with those who do not rise up to the height of an existential and ecstatic exomologesis-

12. In the numbed postmodernity the (pseudo) martyric expression through sacrifice is unfortunately manifesting itself by tenacious cheating, fanaticism, terrorism and holy war, through which some people want to rebuild a world without the Logos and also by anachronistic and heretical rationality of various types (unions, caliphates, federations, sectarianism, etc.). We speak here of the fanaticism of terrorists who blow themselves in the air in order to impress and convince through the meta-logics of death that their religious ideology has indeed a god behind for which they sacrificially commit suicide, ignoring almost totally the logical, reasonable, constructive, metaphysical evaluation of the teachings and vindications of this 'god'. We speak here about the fanaticism of different religious organisations, (Islamism, inquisition, Zionism, legionarism, nazism, brotherhoods, etc.) and (Islamism, political ones (communism, capitalism, socialism, libs, their own martyrs and confessors, intimidation and manipulation, through propaganda and memorialistic works, etc. their own truth and political and religious correctness as a norm of social an communitarian life. We speak here about the arcane subjects of occult organisations that organise Omerta and manipulations that imitate confession and martyrdom requesting astonishment and respect similar to that of a sacrament or mystery. Last but not least we speak about the martyria of a liar prophet, of the prostitute and the apocalyptical beast combined in a confession-homologia of lying, prostitution and their tyrannical mastership over the world that wants to be a nude and libertine confession of truth of a religion that self-imprisons humanity. The doctrine of the false prophet, removes, in fact, through its deceiving game, the confession full of logic and divine wisdom of Christ the Logos that calls man to become god. The confessors of postmodern and post Christian religions and ideologies do not lack courage, expression and impression in accomplishing their unashamed exomolo unashased confession of pseudo virtue and false truth.

13.For example, Saint Spyridon confesses through the miracle of the decomposing brick the mystery of the Holy Trinity, Saint Francis of Assisi confesses Christ before the Sultan of Egypt, Malek al-Kamil, provoking him to convert himself as a result of the miracle of passing through fire in a confrontation of faith in which he manifest himself as totally dedicated to God and totally uncovered and self-relinquished, a fact for which he was named a pioneer of dialogue between civilisations by Muslims themselves. Cf. Interview with Secretary-General of International Islamic Council, Kamel al-Sharif, Rome, 24 Jan 2002, https://web.archive.org/ web/20041105022301/http://www.zenit.org/english/visualizza. phtml?sid=15613. Cf. 'Major Life of St. Francis' by St. Bonaventure, Doctor of the Church. Excerpts from Chapter IX. However, an exemplary exomologesis for a dogmatic dialoguedebate is accomplished in the history of Christian doctrinarian debates by Saint Mark of Ecosus at Mark of Ephesus at the meetings his confession determining that at the end of the meeting, many of the Latins themselves, especially the monks present in the Synod, after listening to the decisions of the Synods and their ins prerpretation performed by Mark, to admit that they had never heard such things before and exclaim that the Greeks are teaching more truthfully than the Latin theologians and wonder at Mark of Ephesus.[130] (Ostroumoff 2005:67). confession. An exomologesis-confession that must be a sincere, logical, non-fanatic affirmation of someone selfidentity and belief, which should convince by the revelation and effective manifestation of God through those participating in the dialogue, as it is manifested through the real martyrs and confessors of the Logos.

The exomologetic dimension, manifested in dialogue by each of the participant parts, should compulsory lead to their mutual embrace in love for the sake of Truth and Good, rediscovered by the revelation of the Logos. A failure in touching on this dimension implicitly involves the deepening of duplicity and spiritual distance between participants missing their focus into the Logos and also the suffering of the most sincere of them. This one will be crowned on another dimension with victory, and the participant with wickedness will be punished for his selfishness, by fights, unrest, divisions, wars and death because they did not honestly raise up to the confession of love. Christ, Himself, in the Gospel, confesses and accuses them from their own statements and by His very presence, refusing to dialogue at ease with Pilate or Caiaphas, because dialogue with them was corrupted by their bad intention as interlocutors, case in which the other side (Christ) must confess the meta-truth about Himself ${ }^{14}$ up to sacrifice and death, trampling down death by death for victory on the other eschatological plan of resurrection.

Precaution and an unwilling spirit, in relation to the ecumenical dialogue of some representatives of traditional Churches, are justified, especially because, pursuing immediate purposes, of mundane, proselyte, material or doctrinarian abstract relationships, the current ecumenical dialogue is developed on a strict psychological dimension on which exterior knowledge could easily install and intentions many times manipulative and dilutive of the liturgical, moral and spiritual ethos and of the dogmatic doctrine of the dialogue partners. The loss is real and important for the partner in dialogue who already lives on the other, ontological, spiritual plan that pursues the ultimate purpose of real (cultic, sacramental) communion through love. From this perspective, confessions and religions must also sincerely evaluate themselves about their own value and of the other possible partners of dialogue according to their coherent, metaphysical, doctrinarian, positively constructive articulation in agreement with the Logos' meta-logics and universal moral law.

In conclusion, despite these dangers of misconducting a dialogue, we must say that staying in dialogue is sometimes inevitable, and, in the end, God created and admitted both the wolf and the lamb; and if their nature is as such that the wolf often kills the lamb and eats it, accusing it unrighteously,

14.John 18:36: Jesus answered, "My kingdom is not of this world. If My kingdom were of this world, My servants would fight, so that I should not be delivered to the Jews; but now My kingdom is not from here'. 
the way that Latin fable says, only because it agitates the water in the stream with his muzzle when it drinks it, still, through the reasoning work of the Logos who is at the centre of dialog and creation, the wolf can become a servant dog, loyal to his human master (even if impure)... and the lamb may become, by the very slaughter of the wolf onto it, Emperor crowned with martyria like Christ the Lamb... The meeting between the two is inevitable, and if we truly want clarifications and changes on the superior ontological plan, on the ethic level of conversion, we must wish for this meeting and the inter-confessional exchanges through which natures enlighten changing their works and personal energies, inevitably accomplishing synergy and conversion or... perversion. He who amazes and convinces with his incarnate and revealed meta-logics, defeats and converts the other! The Christian missionary, who must be in an existential dialogue with those of other beliefs, the way he is described by the Saviour, is sent like the Apostles as the lamb in front of wolves, and he must be wise as a snake and innocent as a dove. He must have a complex personality, not a multiple, pharisaic and fashionable one, but rich and flexible, borrowing even to the maturity of faith, the traits of a bruised reed that the Logos will not break nor hurl (Mt 11, 7; 12:20; Lc 7, 24) just because it is adaptable and able to sit in the dialogue of existence and of exomologetic confession...

\section{Acknowledgements Competing interests}

The author declares that he has no financial or personal relationships that may have inappropriately influenced him in writing this article.

\section{Author's contributions}

V.B. is the sole author of this article.

\section{Ethical considerations}

This article followed all ethical standards for research without direct contact with human or animal subjects.

\section{Funding information}

This project was financed by the Lucian Blaga University of Sibiu \& Hasso Plattner Foundation research grants, LBUSIRG-2021-07.

\section{Data availability}

Data sharing is not applicable to this article as no new data were created or analysed in this study.

\section{Disclaimer}

The views and opinions expressed in this article are those of the author and do not necessarily reflect the official policy or position of any affiliated agency of the author.

\section{References}

Augustin, S., 1933, Confessiones, II, 3, 5; X, 3, 4, t. I and II, Pierre de Labriolle, Paris.

Botezatu, P., 1997, Introducere în logică (Introduction in Logics), Polirom Publishing House, laşi.

Botoşăneanu, C., 2005, Logica Trinităţii (The Logics of Trinity), Gedo PH, Cluj-Napoca.

Biblehub, n.d., Homologia, viewed 01 September 2021, from https://biblehub.com/ greek/3671.htm

Claverie, P., 2015, Mic tratat despre întâlnire şi dialog, Humanitas, Bucureşti.

Foucault, M., 1993, 'About the beginning of the hermeneutics of the self', Political Theory 21(2), 198-227. https://doi.org/10.1177/0090591793021002004

Ică, I.I. Jr., 2001, 'Un ecumenist ortodox în secolul XIV: Împăratul monah loan VI/loasaf Cantacuzino şi proiectul de unire a Bisericilor din 1367', in Ştefan Iloaie (ed.) Logos Arhiepiscopului Bartolomeu al Clujului la împlinirea vârstei de 80 de ani, pp. 321-331, Renaşterea, Cluj Napoca.

Kornarakis, I., 1990, 'Criza de identitate după Sf. Ioan Sinaitul (Scărarul), (The Identity Crisis according to Saint John the Sinait (of the Ladder))', Altarul Banatului, Jan-Feb, pp. 1-2.

Ostroumoff, I.N., 2005, The history of the Council of Florence, transl. from Russian by B. Popoff, Holy Transfiguration Monastery, Boston, MA, 1971. Rom. Transl. C. Făgeţeanu, Romanian editions, Scara EH, 2002; Apologeticum EH.

Rousseau, J.J., 1959 şi 1972, Les Confession, Gallimard, Paris.

Saint John Climacus, 1980, The Ladder, transl. Fr. D. Stăniloae, in Filocalia Română, vol. 9, Ed. Institutului Biblic şi de Misiune al Bisericii Ortodoxe Române, Bucureşti.

Taylor, C., 2008, The culture of confession from Augustine to Foucault: A genealogy of the 'Confessing Animal', Studies in Philosophy, 1st edn., Routledge, s.l.

Tembeck, T., 2009, Performative autopathographies: Self-representations of physical illness in contemporary art, Department of Art History and Communications Studies, McGill University, Montreal.

Tertullian, 1979, 'Liber de poenitentia, “On Repentance"', in A. Roberts \& J. Donaldson (eds.), The Ante-Nicene Fathers, pp. 657-668, Eerdmans, Grand Rapids, MI.

The Archbishop of Westminster (ed.), 1868, 'Of the fervour of his charity, and of his desire of Martyrdom', The Life of Saint Franciss of Assisi, from the 'Legenda Santi Francisci' of S. Bonaventure, p. 251, R. Washbourne, London.

Yannaras, C., 1997, Towards a New Ecumenism, Contacts, No. 179, pp. 202-206, viewed n.d, from https://incommunion.org/2004/10/24/towards-a-new-ecumenism/. 